\title{
An Analysis of Grammatical Errors Committed by Students in Writing Comparison and Contrast Paragraphs
}

\author{
Candra Dwi Yudhayana ${ }^{1 *}$, Putu Adi Krisna Juniarta ${ }^{2}$ iD
${ }_{1,2,3}$ English Language Education, Ganesha University of Education, Singaraja, Indonesia
}

\section{A R T I C L E I N F O}

Article history:

Received September 12, 2021

Revised September 14, 2021

Accepted November 17, 2021

Available online December 25, 2021

Kata Kunci:

Kesalahan Tata Bahasa, Menulis Paragraf, Perbandingan dan Kontras

Keywords:

Grammatical Error, Paragraph Writing, Comparison and Contrast

DOI:

http://dx.doi.org/10.23887/jpbi.v9i3.3 $\underline{8314}$

\section{A B S T R A C T}

Writing skills are still lacking and weak in students' classes and are often ignored by students. This study aimed at analyzing, and calculating the types and the sources of grammatical errors committed by the second-semester students from four classes in the English Language Education department academic year 2020/2021 in their comparison and contrast paragraphs. The final semester test of the Paragraph Writing course was used as the instrument of the study. Additionally, in analyzing the data, the theory by Dulay, Burt, and Krashen (1982) was used to describe the types of errors and the theory by Richards (1974) was used to analyze the errors' sources. After that, that data was calculated. From the 114 paragraphs, 38 paragraphs that contained erroneous sentences were found. Four types of errors were classified, namely omission with 61 errors or $65 \%$, followed by addition with 23 errors or $25 \%$, then misformation with 6 errors or $6 \%$, and the lowest was misordering with 4 errors or $4 \%$. The errors were committed because of two sources; the first was an interlingual error that occurred 52 times or $54.84 \%$ and the second was an intralingual error with 42 errors or $45.16 \%$. Conclusively, the omission and addition errors were the errors that needed to be concerned about because these two types of errors showed a very significant number of occurrences. Therefore, the students should be more aware of the grammar rules and teachers should emphasize the appropriate teaching method or technique to prevent the same errors to be happening in the future.

This is an open-access article under the CC BY-SA license. Copyright (C) 2021 by Author. Published by Universitas Pendidikan Ganesha.

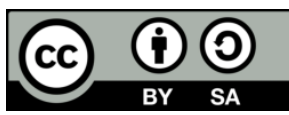

\section{INTRODUCTION}

Writing is an essential skill that every learner has to have. Writing is important not only use in changing communication, yet it is also vitally used in academic interests as well (Alias et al., 2012; Setyowati \& Sukmawan, 2016). Writing is one of the productive skills that should be mastered by the students. In writing, the students can communicate and express their thoughts and feelings, or they can simply write to note something important (Lorena \& Sadiku, 2015; Moses \& Mohamad, 2019). It is also particularly important to have a good capability in writing to keep the information organized and completely communicated (Hill et al., 2020; Wang, 2012). In writing, ideas and thoughts are processed, organized, and revised in such a way (Abednia et al., 2013; Thevasigamoney \& Yunus, 2014). The more the students practice writing, the more proficient they will be at writing. Thus, writing skill is considerably important for the students. As at the university level, the students are expected to be able to accomplish the Paragraph Writing course, specifically in the second semester of the English Language Education department. It is by their principal needs in academic writings where essays, reports, research 
papers, etc. are crucially based on paragraphs. A good paragraph consists of the topic sentence, the body or supporting sentences, and the concluding sentence. Thus, the Paragraph Writing course is a fundamental subject to be completed by the English Language Education students (Bipinchandra et al., 2014; Hashemi \& Mirzaei, 2015). Then, in such a course, writing paragraphs with the topic of comparison and contrast is one of the necessities the students have. Similarly, in comparison and contrast text, it can, indeed, demonstrate two objects or things have different ways to represent one principal point or idea (Baaijen \& Galbraith, 2018; Fu et al., 2019; Vassilaki, 2017). Thus, comparison and contrast text is a text that gives a display of the similarities and differences between certain objects or ideas.

Considering writing is elementally essential in academic interest, still, there is a process the students need to do to be adequately capable in writing. Writing is a process; it consists of steps and needs to be practiced continually to get optimal outcomes (Chen, 2011; Chien, 2012; Wei, 2020). Four principal elements or stages to be followed in conducting writing namely planning, drafting, editing (reflecting and revising), and final draft (Abrams \& Byrd, 2016; Wingate \& Harper, 2021). Before writers are going to write, they have to plan what they need to convey in their writing. There are three important aspects to be considered in the planning stage; the purpose, the audience, and the content structure. After the writers plan their writing, next, they have to precede a draft. The next stage is editing. The draft that has been produced later proceeding to be edited. Several considerations, after reading the draft, are made, such as the clearness of the information, ambiguity, confusion, working or not, considering the structure and detail information, etc. This stage of writing will help the writers to make reflections and revisions based on those considerations. The last stage is the final version of the writing; it, usually, tends to be different compared to the initial draft because of the process of changing with several considerations before (Flores, 2021; Guo \& Huang, 2018; K. W. Chu et al., 2019).

In addition, writing is also considered the most complex skill among the three other skills in English language learning; listening, speaking, and reading (Choi \& Deane, 2020; Dwiyanti et al., 2018). In the four English skills (listening, speaking, reading, and writing), writing skill is the most complex skill because it very much utilizes the work of the mind (Naghdipour, 2021; Sun et al., 2021). This refers to the ideas that have to be invented, the way those ideas are being expressed and delivered, and how they would be constructed into statements, in this case, a piece of a written form. In a writing activity, the cognitive aspect is truly involved to understand the management of ideas in every part of the writing process such as planning, drafting, and revising (Segundo Marcos et al., 2020; Weaver \& Mulgrew, 2021). Thus, writing skill, especially in English language learning, is noticed as the most complex one among other skills. Writing skill is still lack and weak among students (Maysuroh et al., 2017; Setyowati \& Sukmawan, 2016). It is one of the skills that often being neglected by the students, eventually, they face perennially struggle to competently do the writing activity. Under such circumstances, writing is to be a complicated subject to be undertaken by the students, even until the university level (Maysuroh et al., 2017; Moning \& Roelle, 2021). The students suffer difficulties in structural and syntactical components. In addition, he mentions grammatical errors, sentence structure problems, and organization matters are the linguistic problems that they face in making well-formed writing in English. The issues are found in the students' English writing (Fareed et al., 2016). Grammatical and syntactical incompetency, mechanics, idea coherency and expansion, vocabulary, and content organization shortcoming are the major factors to obstruct the students' effective English writing (Nishanthi, 2018; Tammenga-Helmantel et al., 2016). Conclusively, some issues are still found in English writing not only by the students in junior and senior high school but also at the level of the university, especially in the context of grammar.

Considering the fact that the students continuously make errors and mistakes in English writing, understanding the grammar well to compose a good one is a must (Kumala et al., 2018; Tanihardjo, 2016; Uysal \& Yavuz, 2015). Grammar competency settles an important significant position as an essential element in communication competence (Jean \& Simard, 2013; Sharandeep \& Niwas, 2016; Uysal \& Yavuz, 2015). The language cannot be utilized properly and becomes disorganized when there is ignorance for grammar aspects. The importance of grammar competency is in line with the importance of the formality aspect and its form in writing (Benitez-correa et al., 2019; Uysal \& Yavuz, 2015). In other words, the more formal the situation is and it falls on writing, the more grammar is important to be considered (Beydoğan \& Bayındır, 2010; Schurz \& Coumel, 2020). There are some grammar competencies needed to be conceived by the language students, such as word order, grammatical rules; e.g. articles, pluralization, word derivation, etc., morphological and word functions, compounding, conjunctions, logical connectors, contraction, etc. In that case, having competence in grammar concepts is crucial for language students.

There was a study of grammatical errors. The result of this study showed that all of the grammatical error types were found; they were omission error (41.06\%), misformation error (20.22\%), addition error (19.10\%), and misordering error (14.60\%) and with the total of 89 grammatical errors found (Bello, 2017). The finding of the study showed there are 48 errors in total in the students made in their writings (Qamariah et al., 2020). In addition, the errors were categorized into 11 classifications such as verb-used errors, tenses errors, singular/plural noun errors, adjectives errors, preposition errors, to be errors, articles errors, modal/auxiliary errors, noun errors, 
objective pronoun errors, and phrasal verb errors. In conclusion, the grammatical errors made by 10 students of second grade in SMK-SMTI Banda Aceh in their writing showed their flaws in composing good writing (Qamariah et al., 2020). Through the above background, it is shown that grammatical errors analysis in the students' writings is significant to be conducted. However, despite the vast investigation of students' grammatical errors in their writing, there are very limited reviews at the university level, especially in Indonesia. Further, as the same important point, the current study aims at mapping and also obtaining a clear explanation regarding the types and sources of grammatical errors committed by students. The mapping will be very useful to understand the development of the students' grammar knowledge such as the gaps and the lacks that they have in writing, especially in grammar aspects. In short, this study will be useful to develop and select appropriate materials and methods for effective writing teaching and learning. This study aims to analyze and calculate the types and sources of grammatical errors made by second-semester students from four classes in the English Education Department for the 2020/2021 academic year in comparison and contrast.

\section{METHOD}

This study used the descriptive qualitative and quantitative methods; also called mixed-method. The descriptive qualitative method could aid to describe the data which was the grammatical errors committed by students in their comparison and contrast paragraphs. Every sentence in the paragraph was examined based on the appropriate grammar rules. After that, the grammatical errors committed were categorized according to the types of errors. Further, the grammatical errors committed were also identified and classified based on the sources of the errors. In addition, the descriptive quantitative method was used to calculate the frequency of errors that came from the occurrence of the types and the sources of errors. The calculation aimed to rank the percentage amount of grammatical errors committed, thus this helped to predict what errors committed would appear later on. The subject of this study was the second-semester students of four classes in the English Language Education Department, Ganesha University of Education, the academic year 2020/2021. The number of students in a class was about 28-32 students with different levels of English writing competence. Meanwhile, the objects of this study were the 114 pieces of comparison and contrast paragraphs of the students. Additionally, the data was collected through the use of the document collection method and a test. The document collection method was used to collect the students' paragraphs that gather from the results of the final semester test. The final semester test was administered with instructions for the students to write paragraphs according to the topic that had been chosen. Several topics were provided and the students could choose one without any constraint. The number of sentences in a paragraph was limited to at least 12 sentences and the time limit was 70 minutes. Further, this study used the data analysis procedure by Miles and Huberman (1994). After the first step was collecting the data, the next step was data reduction. The data reduction process was done by careful selection of the students' paragraphs through the final semester test. The third step was data display. In this part several steps were performed, such as (1) identifying the students' grammatical errors; (2) determining the grammatical errors; classifying the types and the sources of grammatical errors in the students' paragraphs; and (3) calculating the frequency and percentage of the errors based on the types and sources of errors.

\section{RESULT AND DISCUSSION}

\section{Result}

This study focused on investigating the types and the sources of errors committed by the second-semester students from four classes in the English Language Education department academic year 2020/2021. In conducting the data analysis, there were several procedures had been involved such as data collection, data reduction, data display, and finally concluding. Further, from the four classes, there were 114 comparison and contrast texts in total that had been analyzed. All of the texts were analyzed carefully and systematically which resulted in the finding of 38 erroneous texts regarding the types and sources of errors. In short, more specifications about the analysis will be explained hereafter. The analysis of the types of grammatical errors in this study was based on the "Surface Strategy Taxonomy" theory by (Dulay, Burt, and Krashen, 1982). From the total 114 texts, there 38 texts of comparison and contrast texts errors were found and consisted of 94 types of errors in total. Further, all of the erroneous texts involved all of the error types based on (Dulay, Burt, and Krashen, 1982); omission, addition, misformation, and misordering error. The errors will be shown in Table 1 below.

Table 1. The Classification and Frequency of the Types of Grammatical Errors

\begin{tabular}{ccccc}
\hline No & Error Classifications & Error Types & Frequency & Percentage \\
\hline \multirow{2}{*}{1.} & \multirow{2}{*}{ Omission } & Omission of to be & 12 & $13 \%$ \\
& & Omission of article & 43 & $46 \%$ \\
\hline
\end{tabular}




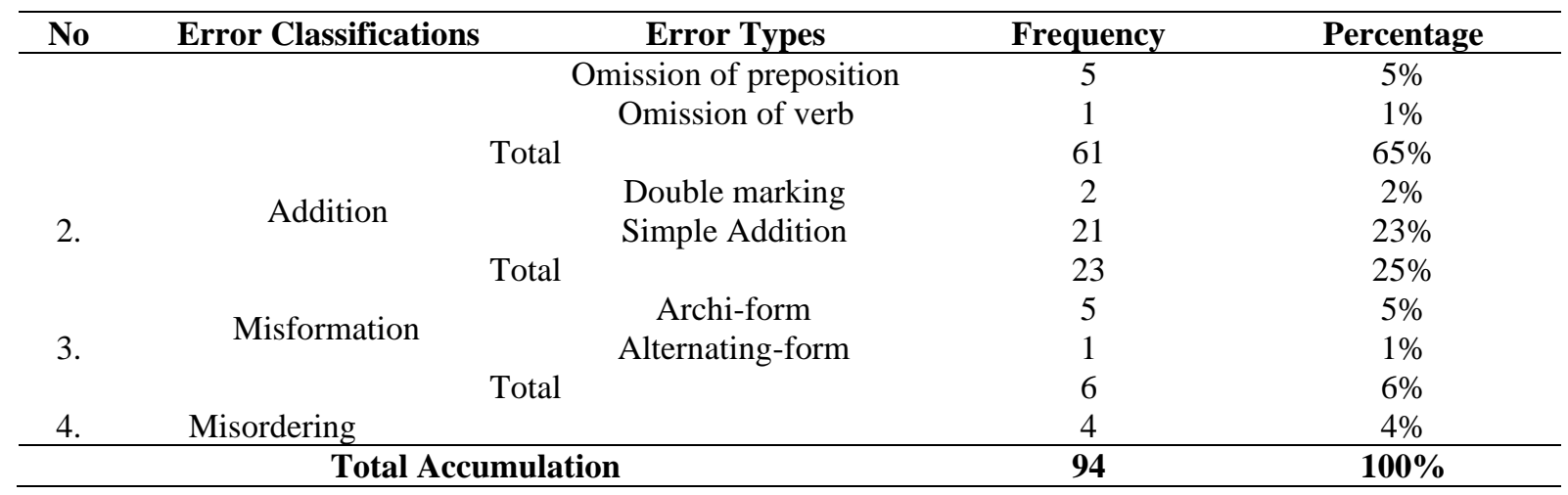

Omission can be categorized as certain items that are omitted in a sentence or utterance. In addition, even though any word in a sentence could probably have the same potential to be omitted, certain words or morphemes are omitted more than others. Following the statements, 61 omission errors were found. The symbol "^^" was represented the omission error type. Thus, the omission error types were classified as follows. First, In the English language, there are "to be" that can be mentioned as they are used in agreement with the subject of the sentence and also related to the tense that is being used. There are five kinds of "to be" in English namely am, is, are, was, and were. By this, there were 12 omissions of "to be" found in the students" compare and contrast paragraphs. These are the examples of such errors;

1.1a) Lots of people use Android because it ^ easy to use ...

1.1b) ...there ${ }^{\wedge}$ students who graduated with qualified...

1.1c) For example, there $\wedge$ a case about two Asian women being harassed on a sidewalk in New York.

Based on the students' compare and contrast paragraphs, the researcher identified 12 omissions of "to be". As can be seen through the examples above, there were three to be's were omitted by the students. In sentence 1.1a, to be "is" was omitted. It was supposed to be mentioned after the word "it". Next, in sentence $1.1 \mathrm{~b}$, to be "were" should be attached after the word "there". Lastly, in sentence 1.1c, to be "is" was needed before the noun phrase "a case" to make the sentence grammatically correct. The corrections from those sentences are shown below;

1.1a) Lots of people use Android because it is easy to use ...

1.1b) ...there were students who graduated with qualified...

1.1c) For example, there is a case about two Asian women being harassed on a sidewalk in New York.

Second, omission of Article. Articles in English are the marking signs for singular and plural nouns. There are two kinds of articles; definite and indefinite. The definite article is "the". It is used before both singular and plural nouns and is also used for nouns that have been mentioned or known earlier. Meanwhile, the indefinite article consists of "a" and "an". The indefinite article is used when a noun is firstly mentioned or a noun that does not already know about it. Based on the data, there 43 omission errors were found. This kind of error was the most error committed by the students in their compare and contrast paragraphs. These errors will be shown below;

$1.2 a)^{\wedge}$ Most important similarity is the team with the highest score wins in a match.

1.2b) As well, Halifax has ^ rainy spring season.

1.2c) The wear pack has ${ }^{\wedge}$ airbag in the back of ${ }^{\wedge}$ rider.

From the example data above, all of the kinds of articles were found. Sentence 1.2a showed that the definite article "the" was omitted. It should have appeared at the beginning of the sentence. Looking at sentence $1.2 \mathrm{~b}$, the indefinite article "a" should be preceding the noun phrase "rainy spring season". In the last example, the sentence $1.2 \mathrm{c}$, two articles were being omitted; they were "an" and "the". The indefinite article "an" should be mentioned before the singular noun which started by a vowel; "airbag", meanwhile the definite article "the" should be put before the noun "rider". The corrections of those sentences should be;

1.2a) The most important similarity is the team with the highest score wins in a match.

1.2b) As well, Halifax has a rainy spring season.

1.2c) The wear pack has an airbag in the back of the rider.

Third, is the Omission of prepositions. A preposition can function as the indicator of a noun phrase relates to the rest of the sentence. Further, the omission of preposition error is the error that occurs because the writer omits the appropriate preposition that should be appeared in a sentence. Those prepositions are in, on, at, by, after, before, to, etc. From the data that was being analyzed, there 5 omissions of prepositions were found. The examples below will show the errors;

1.3a) The facilities in my new school are more complete than ${ }^{\wedge}$ my old school.

1.3b) Pop music tends ^ focus on vocals. 
Considering the two examples above, the students neglected some prepositions. In sentence $1.3 \mathrm{a}$, the preposition "in" should be put before the noun phrase "my old school" and in sentence 1.3b, the student omitted the preposition "to" after the verb "tends". The corrections of those sentences are shown below;

1.3a) The facilities in my new school are more complete than in my old school.

1.3b) Pop music tends to focus on vocals.

Fourth is the Omission of the verb. A verb's function is to give meaning to action in a sentence. In addition, the omission of verb error means the error made by the writer by omitting a verb in a well-formed sentence. About this error, one erroneous sentence was found in the students' paragraphs. This sentence is shown below;

1.4) It is different from Indonesia because Indonesia ^ too much diversity.

From the sentence above, the student omitted a verb which was supposed to be the verb "has". This verb was also used to indicated singular pronouns. Thus, the verb "has" was needed to be put after the noun "Indonesia". The correction would be:

1.4) It is different from Indonesia because Indonesia has too much diversity.

Addition error is the error that happens because of the presence of unneeded items in a well-formed sentence. In other words, addition error is technically the opposite of omission error. Moreover, additional errors can lead readers to confusion and make them unclearly understood because of the unnecessary linguistic items that are being added. Based on Dulay et al. (1982), there are three types of addition errors namely double marking, regularization, and simple addition. Considering this type of error, the researcher found 2 double marking errors and 21 simple addition errors. There was no regularization type of error found in the students' compare and contrast paragraphs. To analyze errors, the sign $\{\ldots\}$ was used. First, double marking. In language constructions, some linguistic items are naturally required in certain sentences. An example is when a sentence is only constructed by one tense (Dulay et al., 1982). In double marking, an error can occur because there is more than one mark in a sentence that makes the sentence grammatically incorrect. As been mentioned previously, there were 2 double marking errors found in the students' paragraphs. These errors can be seen down below;

2.1a) ... my sister \{doesn't seem\} to have an interest...

$2.1 b)$...but people eat food that does not \{contains\} preservatives.

From the two sentences above, the two sentences had the same grammatical error that such error was on the double marking for one tense. Both 2.1a and 2.1b sentences were constructed in the simple present tense. Further, when simple present tense comes to negative forms, the rule for positive or interrogative one is no longer needed. Thus, from the two data above, the verbs "seems" in sentence 2.1 a and the verb "contains" in sentence $2.1 \mathrm{~b}$ should be in their base forms. The corrections of those sentences would be;

2.1a) ... my sister doesn't seem to have an interest...

$2.1 b)$...but people eat food that does not contain preservatives.

Second, simple addition. Simple addition is an error that is not included in both double marking or regularization. There are no particular features categorized as simple addition, yet it is simply the error that happens because linguistic items appeared in well-formed sentences. Based on the students' compare and contrast paragraphs, there were 21 errors found. The examples of those errors are shown down below;

2.2a) ... my brother has $\{a\}$ straight hair, and my sister has $\{a\}$ straight hair, too.

$2.2 b)$... but they \{are\} also have many similarities and differences.

2.2c) Cell phones are much smaller in appearance than $\{a\}$ hardwired phones.

The data above showed examples of simple addition errors made by the students. In the sentence 2.2a, considering that the noun "hair" is an uncountable noun and the article "a", which in this case is the quantifier, fits for countable nouns, thus, this sentence did not need the article "a" to quantify the noun "hair". In sentence $2.2 \mathrm{~b}$, the to be "are" was not supposed to be put because it would spoil the sentence appropriate structure. Lastly, sentence $2.2 \mathrm{c}$ contained an article "a" that was not needed to mark plural noun "phones". All of the corrections will be shown below;

2.2a) ... my brother has straight hair, and my sister has straight hair, too.

2.2b) ... but they also have many similarities and differences.

2.2c) Cell phones are much smaller in appearance than hardwired phones.

Misformation error is the error that occurs because of an incorrect form of sentence structure. Misformation is divided into three categories namely regularization error, archi-form, and alternating-form. In this study, there were two categories found; archi-form (5 errors), and alternating-form (1 error). To investigate misformation error, the symbol [...] was used. First, Archi-form. Archi-form is one of the items in the selected class of forms to represent the other classes. For example, one might select one of the items in the adjectives class of forms; this, these, that, and those, to do things with the items in the nouns class. These are the examples of archi-form errors that were found on the students' compare and contrast paragraphs;

3.1a) Both of [this] activities ...

3.1b) They have to think about how to pour [those] imagination into creation. 
3.1c) You can set [that] alarms twice in 24 hours.

3.1d) [These] stationery can be used to write on book or paper.

From all of those sentences, the students committed errors of the demonstrative adjectives (this, these, that, and those) that they used in their sentences. In sentence 3.1a and 3.1c, the demonstrative adjectives "this" and "that" were not appropriately used because the nouns they identified were singular. On the other hand, $3.1 \mathrm{~b}$ and 3.1 respectively portrayed singular nouns; "imagination" and "stationary". Thus, the demonstrative adjectives "those" and "these" were also incorrect. Then, these were the corrections of those examples;

3.1a) Both of these activities...

3.1b) They have to think about how to pour that imagination into creation.

3.1c) You can set those alarms twice in 24 hours.

3.1d) This stationery can be used to write on book or paper.

Second, Alternating-form. Alternating-form occurs because of the wrong choice of the word added in a sentence. This error is very affected by the language development of the students, especially vocabulary and grammar. About this error, the researcher found one alternating-form error that would be shown below;

3.2) In Indonesia, we [known] and have^ culture about Mahabharata.

The example above showed that the student used the wrong choice of verb. The past participle verb "known" should not be used in explaining the general truth. The verb that was supposed to be used was "know". The correction would be;

3.2) In Indonesia, we know and have the culture about Mahabharata.

Third, Misordering. Misordering is an error type because there is an incorrect morpheme placement in a sentence. Often, the learners made errors because of word-for-word translation based on their native language. In this study, there was four misordering found. Here are the examples of the errors;

4a) The safety is section the main spotlight to be developed...

4b) ...sharp instinct in finding a position or guessing the ball where is going to be.

Based on the above examples, it could be seen that $4 \mathrm{a}$ and $4 \mathrm{~b}$ contain errors. Those errors belong to the misordering type. In sentence 4a, the word "section" was not in an appropriate place. It should be appeared before the to be "is" to make up a noun phrase "The safety section". Then, the second misordering was in the $4 \mathrm{~b}$. The error was between the placement of the noun phrase "the ball" and the relative pronoun of place "where" where the noun phrase "the ball" was supposed to be put after the relative pronoun of place "where" to create a correct form of the relative clause. According to the current analysis, the correction will be;

4a) The safety section is the main spotlight to be developed...

4b) ...sharp instinct in finding a position or guessing where the ball is going to be.

Despite the types, in this study, the sources of grammatical errors were also investigated. There are two sources of errors; interlingual and intralingual error (Richards, 1974). Interlingual error is an error that occurs because the TL's sentences that the students made are influenced by their L1's rules. Meanwhile, an intralingual error occurs because the students break the rules of the TL due to their lack of mastery of the language during the developmental process.

\section{Discussion}

Interlingual error is an error committed by the students because of the influence of the rules of their mother tongue when they are in the process of acquiring L2 (Afshunpour \& Memari, 2014; Amengual, 2018; Bednárová-Gibová, 2016). They use the rules or structures of their mother tongue when using the target language or when producing sentences in the target language without paying attention to the TL's rules (Kirkgöz, 2010; Zaretsky, 2020). Moreover, the interlingual error could be occurring omission error, such as the omission of subjects, verbs, objects, and also misordering error (Mahmoud, 2013; Shamsudin et al., 2013). Thus, in this study, from the data that has been analyzed, it was shown that the interlingual errors committed were 52 errors in total with $54.84 \%$ of percentage. Below are the examples of interlingual errors that were being analyzed, such as;

a)...there ${ }^{\wedge}$ students who graduated with qualified...

b) ...upgrading safety is one thing that can we do to save the life of ${ }^{\wedge}$ racer.

c) Halifax has $\wedge$ rainy spring season.

Based on the above sentences, it can be seen that they are a group of interlingual errors. Firstly, the student omitted to be in his sentence (shown in the first sentence). The to be that should have appeared was the to be for past, "were". It was because the plural noun "students" required plural past marker, which was "were", regarding the existence of existential pronoun "there". However, in forming sentences in Bahasa Indonesia, there are no rules of to be. If the first sentence was translated into Bahasa, it would become a good sentence that said "... ada siswa yang lulus dengan kualifikasi...". Thus, the first sentence was categorized as an interlingual error because the rules of L1 affected the student to form a sentence in TL. Meanwhile, it was different in the second sentence. If it is examined more deeply, then the error that occurred lying in the incorrectness of the word placement or better known as misordering error. The error was the misorder of the modal verb "can" and the pronoun "we". The 
placement between the two was inverted; the pronoun "we" should precede the modal verb "can". Yet, in Bahasa, the order of this sentence was correct and acceptable as it would say "...meningkatkan keselamatan adalah satu hal yang bisa kita lakukan untuk menyelamatkan nyawa pembalap.”. In short, the second sentence was included as an interlingual error. As in the first sentence, the last erroneous sentence analyzed was also dealing with the omission error. The linguistic item omitted there was the indefinite article " $a$ ". It comes before the consonant nouns and marks the number of countable nouns. As in this sentence, the indefinite article "a" should have appeared before the noun phrase "rainy spring season" to make the sentence grammatically correct. The student who committed this error was influenced by the grammatical rules of his L1 (Bahasa Indonesia). If it was translated into Bahasa, it would be "Halifax memiliki musim semi yang berhujan". It showed that there was no requirement to put any linguistic items again and the sentence was fairly acceptable in Bahasa (Khalil, 2018; Tanihardjo, 2016). Therefore, this sentence is categorized as an interlingual error. To cover up, here are all of the sentences after correction;

a)...there were students who graduated with qualified...

b) ...upgrading safety is one thing that we can do to save the life of the racer.

c) Halifax has a rainy spring season.

The intralingual error happens because of the students' incomplete mastery of the target language rules (Gvarishvili, 2013; Villwock et al., 2021; Zafar, 2016). Intralingual error is also called a developmental error because the students are still in the process of acquiring the target language. Moreover, this error embodies overgeneralization, an incomplete understanding, a false conception, and an ignorance of the rules of the target language (Ávila-Cabrera \& Esteban, 2021; Gvarishvili, 2013). About this study, the intralingual errors committed by the students in their paragraphs were 42 errors with $45.16 \%$ in total. Here are the examples of the intralingual errors committed by the students in their paragraphs;

a) After their death, both Presidents ${ }^{\wedge}$ succeeded by the vice-president named Johnson.

b) Cell phones are much smaller in appearance than $\{a\}$ hardwired phones.

c) [That] differences and similarities of pop and rock music...

Based on the three examples of erroneous sentences above, the researcher included them in the intralingual error category. In the first sentence, the student who committed this error appeared to be ignoring the rule of the English passive voice where it was supposed to be "be + past participle". In the sentence, the student omitted the to be for past which caused the sentence to be grammatically incorrect. Consequently, the to be that should be written was "were" to complete the student's passive voice sentence. Then, in the second sentence, another error was found in the aspect of intralingual. The sentence was added by an unnecessary item which was an indefinite article "a". The article was put unnecessarily because it was supposed to mark singular nouns and, as a result, broke the English grammar rule regarding the use of the article. After all, the second sentence possessed a plural noun phrase "hardwired phones" instead. In that case, the sentence needed no articles. Lastly, the third sentence contained a different case of error. In the English language, there are called demonstrative adjectives (this, these, that, and those). These adjectives are the marking signs of the nouns they assess, whether singular or plural. From the example given, the last sentence is explicitly shaped in a plural one. Therefore, the use of the demonstrative adjective "that" seemed to be inappropriate and needed to be replaced by the demonstrative adjective "those". Conclusively, all of the three sentences correction can be considered as follows;

a) After their death, both Presidents were succeeded by the vice-president named Johnson.

b) Cell phones are much smaller in appearance than hardwired phones.

c) Those differences and similarities of pop and rock music...

Finally, there are some suggestions for students, teachers, and also other researchers. For students, the students need to improve their competency in writing, especially about the English grammar from this study. From the data analysis, the students can decrease and prevent the same errors in the future. For teachers, this study can be used to help to encounter the students' difficulties in writing regarding English grammar. Further, based on the data analysis, the teachers can also design appropriate learning methods or techniques to lessen and prevent the students' grammatical problems in writing in the future. Lastly, for other researchers, it would be better to do repetitive analysis if other researchers intend to conduct a study with a similar topic, method, or design to enrich the inquiry of grammatical errors in the students' writings.

\section{CONCLUSION}

Based on these findings and discussion, students still made grammatical errors in their writing. It can happen even at the university level. Based on the grammatical errors made by the second-semester students of the four English Education classes for the 2020/2021 academic year in the comparison and contrast paragraphs, the analysis shows that 94 grammatical errors were found entirely. Next is the type of misformation error. The error type with the lowest number is the ordering error. This type of error is considered the minor error made by students in the comparison paragraph, and the contrast with the total errors found is 4 or $4 \%$. Based on data analysis, it 
shows that deletion and addition errors need to be considered. These two types of errors equal $90 \%$ of all errors committed. The figure shows a significant result illustrating the common control over English grammar, which causes deletion and addition errors. As for the source of the error shows that there are two sources of error found; interlingual errors and intralingual errors.

\section{REFERENCES}

Abednia, A., Hovassapian, A., Teimournezhad, S., \& Ghanbari, N. (2013). Reflective journal writing: Exploring in-service EFL teachers' perceptions. System, 41(1). https://doi.org/10.1016/j.system.2013.05.003.

Abrams, Z. I., \& Byrd, D. R. (2016). The effects of pre-task planning on L2 writing: Mind-mapping and chronological sequencing in a 1st-year German class. System, 63. https://doi.org/10.1016/j.system.2016.08.011.

Afshunpour, N., \& Memari, M. (2014). Interlingual Transfer of Idioms by Persian Learners in EFL Sentence Writing. Procedia - Social and Behavioral Sciences, 98. https://doi.org/10.1016/j.sbspro.2014.03.387.

Alias, A. A., Manan, N. A. A., Yusof, J., \& Pandian, A. (2012). The use of Facebook as Language Learning Strategy (LLS) Training Tool on College Students' LLS use and Academic Writing Performance. Procedia - Social and Behavioral Sciences, 67. https://doi.org/10.1016/j.sbspro.2012.11.305.

Amengual, M. (2018). Asymmetrical interlingual influence in the production of Spanish and English laterals as a result of competing activation in bilingual language processing. Journal of Phonetics, 69. https://doi.org/10.1016/j.wocn.2018.04.002.

Ávila-Cabrera, J. J., \& Esteban, A. C. (2021). The project SubESPSKills: Subtitling tasks for students of Business English to improve written production skills. English for Specific Purposes, 63. https://doi.org/10.1016/j.esp.2021.02.004.

Baaijen, V. M., \& Galbraith, D. (2018). Discovery Through Writing : Relationships with Writing Processes and Text Quality Discovery Through Writing : Relationships with Writing Processes. Cognition and Instruction, O(0), 1-25. https://doi.org/10.1080/07370008.2018.1456431.

Bednárová-Gibová, K. (2016). Acquis Communautaire as Supranational Legal Texts and their Interlingual Reproduction across Multilingual Europe. Procedia - Social and Behavioral Sciences, 236. https://doi.org/10.1016/j.sbspro.2016.12.058.

Bello, P. M. (2017). An analysis of grammatical errors in written descriptive text by the first year students of Vocational School of Economics and Commerce Becora, Dili East Timor in School Year 2016/2017. International Journal of Advanced Research, 5(9). https://doi.org/10.21474/IJAR01/5354.

Benitez-correa, C., Gonzalez-torres, P., \& Ochoa-cueva, C. (2019). A Comparison between Deductive and Inductive Approaches for Teaching EFL Grammar to High School Students. International Journal of Instruction, 12(1). https://doi.org/10.29333/iji.2019.12115a.

Beydoğan, H. Ö., \& Bayındır, G. (2010). Effect of concept map supported teaching approaches from rules to sample and sample to rules to grammar teaching. Procedia - Social and Behavioral Sciences, 2(2). https://doi.org/10.1016/j.sbspro.2010.03.623.

Bipinchandra, J. S. a/p, Shah, P. M., Puteh, S. N., Din, R., Rahamat, R., \& Aziz, J. A. (2014). User Needs Analysis in Learning Argumentative Writing Via Mobile Platform. Procedia - Social and Behavioral Sciences, 118. https://doi.org/10.1016/j.sbspro.2014.02.027.

Chen, Y. (2011). Study of the writing strategies used by Chinese non-English majors. Theory and Practice in Language Studies, 1(3), 245-251. https://doi.org/10.4304/tpls.1.3.245-251.

Chien, S. C. (2012). Students use of writing strategies and their English writing achievements in Taiwan. Asia Pacific Journal of Education, 32(1), 93-112. https://doi.org/10.1080/02188791.2012.655240.

Choi, I., \& Deane, P. (2020). Evaluating Writing Process Features in an Adult EFL Writing Assessment Context: A Keystroke Logging Study. Language Assessment Quarterly, 00(00), 1-26. https://doi.org/10.1080/15434303.2020.1804913.

Desnaranti, L. (2018). Morphological and Syntactical Error Analysis on Students' Procedure Text Writings. In Scope: Journal of English Language Teaching (Vol. 1, Issue 02, p. 159). https://doi.org/10.30998/scope.v1i02.1121.

Dwiyanti, L., Khan, R. I., \& Kurniawati, E. (2018). Development of Smart Adventure Games to Improve the Readiness of the Initial Ability of Reading, and Writing on Early Childhood. Jurnal Obsesi : Jurnal Pendidikan Anak Usia Dini, 2(2), 149. https://doi.org/10.31004/obsesi.v2i2.91.

Fareed, M., Ashraf, A., \& Bilal, M. (2016). ESL learners' writing skills: Problems, factors and suggestions. Journal of Education and Social Sciences, 4(2). https://doi.org/10.20547/jess0421604201. 
Flores, J. A. A. (2021). The semiotics of writing: How adult L2 learners with emergent literacy make meaning in assessment texts through writing. Journal of Second Language Writing, 51. https://doi.org/10.1016/j.jslw.2021.100793.

Fu, Q.-K., Lin, C.-J., Hwang, G.-J., \& Zhang, L. (2019). Impacts of a mind mapping-based contextual gaming approach on EFL students' writing performance, learning perceptions and generative uses in an English course. Computers \& Education, 137. https://doi.org/10.1016/j.compedu.2019.04.005.

Guo, X., \& Huang, L. S. (2018). Are L1 and L2 strategies transferable? An exploration of the L1 and L2 writing strategies of Chinese graduate students. Language Learning Journal, O(0), 1-23. https://doi.org/10.1080/09571736.2018.1435710.

Gvarishvili, Z. (2013). Interference of L1 Prepositional Knowledge in Acquiring of Prepositional Usage in English. Procedia - Social and Behavioral Sciences, 70. https://doi.org/10.1016/j.sbspro.2013.01.224.

Hashemi, Z., \& Mirzaei, T. (2015). Conversations of the Mind: The Impact of Journal Writing on Enhancing EFL Medical Students' Reflections, Attitudes, and Sense of Self. Procedia - Social and Behavioral Sciences, 199. https://doi.org/10.1016/j.sbspro.2015.07.493

Hill, C., Khoo, S., \& Hsieh, Y.-C. (2020). An investigation into the learning transfer of English for specific Academic Purposes (ESAP) writing skills of students in Singapore. Journal of English for Academic Purposes, 46. https://doi.org/10.1016/j.jeap.2020.100908.

Jean, G., \& Simard, D. (2013). Deductive versus inductive grammar instruction: Investigating possible relationships between gains, preferences and learning styles. System, 41(4). https://doi.org/10.1016/j.system.2013.10.008.

K. W. Chu, S., Wu, J., W. S. Kwan, C., \& H. Y. Lai, J. (2019). Wiki-based Collaborative Writing: A Comparative Study on First and Second Language Writing among Chinese Secondary Students. International Journal of Modern Education and Computer Science, 11(1), 1-10. https://doi.org/10.5815/ijmecs.2019.01.01.

Khalil, Z. M. (2018). EFL Students' Perceptions towards Using Google Docs and Google Classroom as Online Collaborative Tools in Learning Grammar. Applied Linguistics Research Journal, 2(2), 3348. https://doi.org/10.14744/alrj.2018.47955.

Kirkgöz, Y. (2010). An analysis of written errors of Turkish adult learners of English. Procedia - Social and Behavioral Scienc, 2(2). https://doi.org/10.1016/j.sbspro.2010.03.692.

Kumala, B. P., Aimah, S., \& Ifadah, M. (2018). An analysis of grammatical errors on students' writing. ELLiC Proceedings, 2. https://doi.org/10.22460/project.v2i6.p764-770.

Lorena, C., \& Sadiku, M. (2015). The Importance of Four Skills Reading, Speaking, Writing, Listening in a Lesson Hour. European Journal of Language and Literature Studies, 1(1), $29-31$. https://doi.org/10.26417/ejls.v1i1.p29-31.

Mahmoud, A. (2013). A linguistic perspective of the effect of English on MSA: Manifestations and ramifications. Journal of King Saud University - Languages and Translation, 25(1). https://doi.org/10.1016/j.jksult.2012.10.001.

Maysuroh, S., Maryadi, L. I., \& Supiani. (2017). Students' English writing process and problems: A case study at Hamzanwadi University. Voices of English Language Education Society, 1(1). https://doi.org/10.29408/veles.v1i1.388.

Moning, J., \& Roelle, J. (2021). Self-regulated learning by writing learning protocols: Do goal structures matter? Learning and Instruction, 75. https://doi.org/10.1016/j.learninstruc.2021.101486.

Moses, R. N., \& Mohamad, M. (2019). Challenges Faced by Students and Teachers on Writing Skills in ESL Contexts: A Literature Review. Journal Scientific Reseacrh, 10, 3385-3391. https://doi.org/10.4236/ce.2019.1013260.

Naghdipour, B. (2021). English writing pedagogy at the crossroads: The case of Oman. Journal of Second Language Writing, 52. https://doi.org/10.1016/j.jslw.2021.100815.

Nishanthi, R. (2018). The Importance of Learning English in Today World. International Journal of Trend in Scientific Research and Development, 3(1), 871-874. https://doi.org/10.31142/ijtsrd19061.

Qamariah, H., Wahyuni, S., \& Meliana. (2020). An analysis of students' grammatical errors in writing English text in the second grade students of SMK-SMTI Banda Aceh. Getsempena English Education Journal, 7(1). https://doi.org/10.21474/IJAR01/5354.

Richards, J. C. (2015). Error analysis: Perspectives on second language acquisition. In Error Analysis: Perspectives on Second Language Acquisition (pp. 1-228). https://doi.org/10.4324/9781315836003.

Schurz, A., \& Coumel, M. (2020). Grammar teaching in ELT : A cross-national comparison of teacherreported practices. Language Teaching Research, 8. https://doi.org/10.1177/1362168820964137.

Segundo Marcos, R. I., López Ferández, VerSegundo Marcos, R. I., López Ferández, V., Daza González, M. T., \& Phillips-Silver, J. (2020). Promoting Children's Creative Thinking Through Reading and 
Writing in A Cooperative Learning Classroom. Thinking Skills and Creativity, 36(Ju, 100663. https://doi.org/10.1016/j.tsc.2020.100663ónica, Daza González, M. T., \& Phillips-Silver, J. (2020). Promoting Children's Creative Thinking Through Reading and Writing in A Cooperative Learning Classroom. Thinking Skills and Creativity, 36(June 2019), 100663. https://doi.org/10.1016/j.tsc.2020.100663.

Setyowati, L., \& Sukmawan, S. (2016). EFL Indonesian Students' Attitude toward Writing in English. Arab World English Journal (AWEJ), 7(4). https://doi.org/10.24093/awej/vol7no4.24.

Shamsudin, S., Sadoughvanini, S., \& Zaid, Y. H. (2013). Iranian EFL Learners' Collocational Errors in Speaking Skill. Procedia - Social and Behavioral Sciences, 70. https://doi.org/10.1016/j.sbspro.2013.01.190.

Sharandeep, K., \& Niwas, D. R. (2016). Introduction : - Role of Grammar in English Language : - Methods of Teaching Grammar : - Review of Related Literature. International Journal of Advanced Research, 4(7). https://doi.org/10.21474/IJAR01.

Sun, T., Wang, C., Lambert, R. G., \& Liu, L. (2021). Relationship between second language English writing self-efficacy and achievement: A meta-regression analysis. Journal of Second Language Writing, 53. https://doi.org/10.1016/j.jslw.2021.100817.

Tammenga-Helmantel, M., Bazhutkina, I., Steringa, S., \& Hummel, I. (2016). Comparing inductive and deductive grammatical instruction in teaching German as a foreign language in Dutch classrooms. System, 63. https://doi.org/10.1016/j.system.2016.09.002.

Tanihardjo, J. (2016). The Analysis of Students' English Competence in the Grammar Section in the PaperBased TOEFL: A Case Study at English Department in Bunda Mulia University. Journal of English Language \& Culture, 6(1). https://doi.org/10.30813/jelc.v6i1.270.

Thevasigamoney, A. F., \& Yunus, M. M. (2014). A Glimpse into E-Mail Dialogue Journal Writing (EDJW) and Writing Anxiety among Gifted Learners. Procedia - Social and Behavioral Sciences, 123. https://doi.org/10.1016/j.sbspro.2014.01.1423.

Uysal, N. D., \& Yavuz, F. (2015). Pre-Service Teachers' Attitudes Towards Grammar Teaching. Procedia Social and Behavioral Sciences, 191. https://doi.org/10.1016/j.sbspro.2015.04.353.

Vassilaki, E. (2017). Reflective writing, reflecting on identities: The construction of writer identity in student teachers' reflections. Linguistics and Education, 42. https://doi.org/10.1016/j.linged.2017.08.001.

Villwock, A., Wilkinson, E., Piñar, P., \& Morford, J. P. (2021). Language development in deaf bilinguals: Deaf middle school students co-activate written English and American Sign Language during lexical processing. Cognition, 211. https://doi.org/10.1016/j.cognition.2021.104642.

Wang, Y. (2012). Differences in L1 and L2 academic writing. Theory and Practice in Language Studies, 2(3), 637-641. https://doi.org/10.4304/tpls.2.3.637-641.

Weaver, R. M., \& Mulgrew, K. E. (2021). The effectiveness of positive appearance and functionality reflective writing tasks on state body image and response to idealised media exposure among 35-60 year-old women. Body Image, 37. https://doi.org/10.1016/j.bodyim.2021.02.008.

Wei, X. (2020). Assessing the metacognitive awareness relevant to L1-to-L2 rhetorical transfer in L2 writing: The cases of Chinese EFL writers across proficiency levels. Assessing Writing, 44(September 2019), 100452. https://doi.org/10.1016/j.asw.2020.100452.

Wingate, U., \& Harper, R. (2021). Completing the first assignment: A case study of the writing processes of a successful and an unsuccessful student. Journal of English for Academic Purposes, 49, 100948. https://doi.org/10.1016/j.jeap.2020.100948.

Zafar, A. (2016). Error Analysis: A Tool to Improve English Skills of Undergraduate Students. Procedia Social and Behavioral Sciences, 217. https://doi.org/10.1016/j.sbspro.2016.02.122.

Zaretsky, E. (2020). English spelling acquisition by English Language Learners from Spanish-speaking background: The role of cognitive and linguistic resources and $\mathrm{L} 1$ reading status. Cognitive Development, 55. https://doi.org/10.1016/j.cogdev.2020.100918. 